\title{
Kajian Tingkat Penerapan Manajemen Mutu pada UMKM Pengolah Ikan Pindang Tradisional dan Higienis di Kabupaten Bogor
}

\author{
The Study of Quality Management Implementation Level on Traditional and Hygienic Boiled Fish \\ Processing SMEs in Bogor Regency
}

\author{
Lisa Bremanti ${ }^{1^{*}}$, Musa Hubeis ${ }^{2 \sharp}$, dan Nurheni Sri Palupi ${ }^{3 \#}$ \\ ${ }^{1}$ Kementerian Kelautan dan Perikanan \\ 2 Departemen Manajemen, Fakultas Ekonomi dan Manajemen Institut Pertanian Bogor \\ ${ }^{3}$ Departemen Ilmu dan Teknologi Pangan, Fakultas Teknologi Pertanian Institut Pertanian Bogor \\ * Jl. Kamper, Kampus IPB Darmaga Bogor 16680
}

\begin{abstract}
ABSTRAK
Pemindangan merupakan pengolahan hasil perikanan yang memiliki potensi besar karena diminati oleh masyarakat pada umumnya. UMKM Cindy Group merupakan UMKM di kabupaten Bogor yang berkeinginan agar produk yang dihasilkannya mampu berdaya saing, sehingga dibutuhkan penerapan manajemen mutu. Tujuan penelitian ini: (1) mengidentifikasi tingkat penerapan manajemen mutu pada UMKM pengolah ikan pindang tradisional dan higienis, serta (2) menganalisis hubungan tingkat penerapan mutu terhadap kinerja UMKM pengolah ikan pindang tradisional dan higienis. Metode yang digunakan adalah analisis deskriptif; analisis tren (kinerja keuangan: Net Profit Margin (NPM), Return on Investment (ROI), Return on Equity (ROE) dan kinerja non keuangan: jumlah pelatihan, volume produksi, jumlah pelanggan); dan analisis diskriminan. Teknik pengambilan contoh untuk pengisian kuesioner menggunakan purposive sampling. Hasil kajian menunjukkan tingkat penerapan sistem manajemen mutu pada pemindangan tradisional berada pada tingkat diantara Operator Quality Control (OQC) dan Foreman Quality Control (FQC), sedangkan pemindangan higienis berada pada tingkat diantara Statistic Quality Control (SQC) dan Total Quality Management (TQM). Hasil analisis diskriminan menunjukkan bahwa tingkat penerapan Sistem Manajemen Mutu (SMM) berpengaruh terhadap kinerja perusahaan UD Cindy Group, yaitu pada kinerja keuangan dan non keuangan yaitu dilihat dari nilai sig $<0.05$. Pada pemindangan higienis memiliki tren kinerja non keuangan yang meningkat dan lebih tinggi pada rataan tiga tahun terakhir dibandingkan dengan pemindangan tradisional.
\end{abstract}

Kata kunci: kinerja perusahaan, pemindangan, pengolah ikan pindang, sistem manajemen mutu

\begin{abstract}
Boiled fish is a processing of fishery products that have great potential because of high public demanding. UMKM Cindy Group is a small and medium enterprise in Bogor regency who wished that their product could be competitive, so that the application of quality management is required. The objectives of this research were: (1) to identify the level of quality management implementation at traditional and hygienic boiled fish SMEs as well as; (2) to analyze the relation of the level of quality application to the performance of traditional and hygienic boiled fish SMEs. The method used was descriptive analysis; trend analysis (financial performance: Net Profit Margin (NPM), Return on Investment (ROI), Return on Equity (ROE) and non-financial performance (number of training, production volume, number of customers); and discriminant analysis. Sampling technique for filling questionnaire was purposive sampling. The results of the study found that the level of application of quality management system at traditional boiled fish was at the level between Quality Control Operator (OQC) and Foreman Quality Control (FQC), while hygienic cleansing was at the level between Statistic Quality Control (SQC) and Total Quality Management (TQM). The result of discriminant analysis show that the level of SMM implementation has an effect on the company performance of UD Cindy Group

\footnotetext{
*) Korespondensi:

Lapangan Member Perum Mutiara Buana no A9 RT. 1/4 Sukmajaya, Depok; email: lisabremanti@gmail.com
} 
that was seen from sig value $<0.05$. On hygienic displacement had an increasing trend of non-financial performance and higher on the average of the last three years compared with traditional boiled fish.

Key words: boiled fish, boiled fish processor, company performance, quality management system

\section{PENDAHULUAN}

Dalam era globalisasi persaingan bisnis menjadi sangat kompetitif, baik di pasar domestik (nasional) maupun di pasar internasional (global). Perusahaan-perusahaan dihadapkan pada berbagai peluang dan ancaman, baik dari luar maupun dari dalam negeri. Indonesia saat ini memasuki era pertumbuhan ekonomi yang sangat nyata. Indonesia menjadi negara dengan pertumbuhan ekonomi terbesar ketiga di dunia pada tahun 2009 dan menjadi negara dengan ekonomi terbesar ke-17 di dunia berdasarkan pencapaian product domestic bruto (PDB). Pertumbuhan ekonomi di Indonesia tidak lepas dari peran UKM yang menopang pertumbuhan ekspor dan impor.

Subsektor perikanan dan peternakan merupakan andalan utama sumber pangan dan gizi masyarakat Indonesia (Heruwati, 2002). Wilayah Indonesia yang memiliki potensi perikanan dapat dikembangkan, salah satunya wilayah Jawa Barat. Pengolahan ikan bertujuan untuk meningkatkan nilai tambah pada bahan baku ikan, dengan tetap konsisten menjaga mutu dan nutrisi yang terkandung dalam ikan sehingga konsumen dapat mengkonsumsi produk dengan aman dan memperoleh manfaat bagi tubuhnya. Pengawetan ikan dapat dilakukan melalui pengolahan seperti pengeringan/pengasinan, pemindangan, pengasapan, peragian dan pengolahan lainnya. Berdasarkan data jumlah unit pengolahan ikan secara tradisional di Indonesia (KKP dalam Angka 2009-2012 diolah), pemindangan ikan di Indonesia jumlahnya menempati posisi kedua setelah penggaraman dengan laju pertumbuhan $4,03 \%$ per tahun. Pindang, merupakan olahan ikan yang sudah dikenal lama oleh masyarakat di Indonesia dan sangat diminati, terutama untuk kalangan menengah ke bawah karena rasanya khas, praktis, harganya terjangkau dan memiliki nilai gizi lebih baik daripada ikan asin.

Pada dasarnya penerapan manajemen mutu sangat diperlukan oleh suatu perusahaan untuk menjamin produk dan jasa yang dihasilkannya selalu memuaskan konsumen secara konsisten dari waktu ke waktu. Dalam hal ini, agar UKM di Indonesia mampu berdaya saing dengan produk- produk dari negara lain dibutuhkan peningkatan mutu produk dan efisiensi produksi dengan penerapan manajemen mutu.

Tujuan penelitian adalah (1) Mengidentifikasi tingkat penerapan manajemen mutu pada UMKM pengolah ikan pindang tradisional dan higienis; (2) Menganalisis tingkat penerapan mutu terhadap kinerja UMKM pengolah ikan pindang tradisional dan higienis.

\section{METODE PENELITIAN}

\section{Pengumpulan Data}

Metode pengumpulan data menggunakan kuesioner. Sumber data terdiri atas: (1) Data Primer (profil perusahaan, data aktivitas keuangan perusahaan dan data pendukung produksi; (2) Data Sekunder berasal dari eksternal perusahaan seperti KKP, Dinas Peternakan dan Perikanan Kabupaten Bogor, Dinas Kelautan dan Perikanan Provinsi Jawa Barat, KKOP dan UKM, APPIKANDO, BPS, melalui penelusuran buku, jurnal, tesis, literatur dari internet dan artikel lainnya yang berkaitan dengan topik kajian.

Penelitian ini menggunakan kuesioner (modifikasi dari penelitian Panjaitan, 2011), dengan narasumber adalah karyawan dari UMKM Cindy Group. Metode penentuan contoh yang digunakan adalah purposive sampling dengan 10 narasumber untuk pemindangan tradisional dan 18 narasumber untuk pemindangan higienis.

\section{Pengolahan dan Analisis Data}

Analisis deskriptif bertujuan menjelaskan atau mendeskripsikan karakteristik responden dan peubah yang diteliti. Analisis deskriptif pada penelitian penentuan tingkat penerapan SMM dilakukan dengan mencocokkan upaya-upaya mutu yang telah diterapkan oleh UMKM Cindy Group, dengan ciri-ciri tingkat penerapan SMM sesuai dengan Muhandri dan Kadarisman (2006), dapat dilihat pada Tabel 1.

Analisis Kinerja Keuangan pada pemindangan tradisional dan higienis meliputi: (1) Kinerja Keuangan (Net Profit Margin/NPM, Return on Investment/ROI dan Return on Equity/ROE); (2) Kinerja Non Keuangan (Jumlah Pelatihan, Volume Produksi dan Jumlah Pelanggan). 
Tabel 1 . Ciri-ciri tingkat penerapan SMM

\begin{tabular}{|c|c|c|}
\hline No. & Tingkat Penerapan SMM & Ciri Utama \\
\hline 1. & Operator QC & $\begin{array}{l}\text { - Seorang atau sekelompok kecil orang membuat barang secara utuh } \\
\text { - Karyawan mengendalikan sendiri seluruh pekerjaannya }\end{array}$ \\
\hline 2. & Foreman QC & $\begin{array}{ll}\text { - } & \text { Karyawan dikelompokkan menurut jenis pekerjaan (spesialisasi) } \\
\text { - } & \text { Seorang (mandor) yang tidak terlibat dalam pekerjaan menghasilkan } \\
& \text { produk dan melakukan pengawasan }\end{array}$ \\
\hline 3. & Inspection QC & $\begin{array}{l}\text { - Adanya "full time inspector" } \\
\text { _ } \quad \text { Unit kerja pemeriksaan (inspeksi) terpisah dari unit kerja produksi }\end{array}$ \\
\hline 4. & Statistic QC & $\begin{array}{l}\text { - Pemeriksaan dilakukan terhadap contoh yang diambil secara acak } \\
\text { - } \quad \text { Penggunaan teknik Sampling dan Control Chart }\end{array}$ \\
\hline 5. & QA & $\begin{array}{l}\text { - Pengendalian mutu dengan Teknik Statistik tetap dilakukan } \\
\text { - } \text { Berbagai departemen (bagian) terlibat dalam kegiatan mutu dengan } \\
\text { menerapkan Plan-Do-Check-Act (P-D-C-A) }\end{array}$ \\
\hline 6. & TQM & $\begin{array}{l}\text { - Menitikberatkan pada pendekatan mutu dari berbagai aspek manajemen } \\
\text { seperti perencanaan mutu, pengendalian mutu dan perbaikan mutu } \\
\text { - Menerapkan suatu standar SMM seperti ISO-9000, Malcolm Baldridge dan } \\
\text { atau Six-Sigma }\end{array}$ \\
\hline
\end{tabular}

Sumber: Muhandri dan Kadarisman, 2006.

Kinerja perusahaan dari segi keuangan dan non keuangan dianalisis menurut kecenderungan atau tren terhadap aspek SMM yang dikaji. Analisis tren digunakan untuk menganalisis kondisi kinerja keuangan dan non-keuangan perusahaan pengolahan ikan pindang tradisional dan higienis dalam periode kajian. Analisis diskriminan merupakan teknik analisis data, dimana peubah dependen merupakan data kategorik atau kualitatif (ordinal atau rasio) dan peubah independen berupa data kuantitatif (interval atau rasio). Perhitungan dengan menggunakan bantuan perangkat lunak komputer (software) program SPSS (Statistical Package for Social Sciences) versi 21.0 for windows. Tujuan analisis diskriminan adalah menganalisis ada tidaknya perbedaan nyata kinerja perusahaan pengolahan pindang tradisional dan higienis, serta menentukan peubah mana yang memberikan kontribusi terbesar terhadap perbedaan yang terjadi pada perusahaan tersebut.

\section{HASIL DAN PEMBAHASAN}

\section{Tingkat Penerapan Sistem Manajemen Mutu}

Hasil pengamatan, wawancara dan observasi terhadap UD Cindy Group pada tingkat penerapan SMM pemindangan tradisional dan higienis terlihat pada Gambar 1, yaitu pemindangan tradisional berada diantara tahap tingkat pertama (OQC) dengan nilai 1,9 dan tingkat kedua (FQC) dengan nilai 2,35 dari enam tingkat penerapan SMM (Tabel 2) sesuai Feigenbaum dalam Muhandri dan Kadarisman (2006). Skor yang diperoleh untuk OQC dan FQC apabila dibulatkan adalah dua, yaitu "setuju". OQC artinya pekerjaan membuat produk dikerjakan oleh seorang karyawan atau sejumlah kecil karyawan secara mandiri (membuat produk hingga memeriksa produk akhir), sedangkan FQC artinya telah ada seorang mandor yang melakukan pengawasan terhadap proses produksi. Hal tersebut menunjukkan bahwa beberapa kelompok pemindangan tradisional telah meningkatkan penerapan SMM dengan menambah SDM yang bertugas mengawasi jalannya proses produksi. Pada pemindangan tradisional belum memperhatikan mutu produk dimana proses produksi yang dilakukan belum memenuhi standar. Belum ada sistem yang terkendali untuk menjaga mutu yang menjamin bahwa sudah dilakukan pemeriksaan terhadap mutu produk. Dari hasil penelitian Wardana (2006) menyatakan bahwa faktor yang paling berpengaruh atau penting terhadap perubahan kinerja perusahaan adalah penerapan SMM, disusul kemudian faktor lainnya, yaitu persaingan produk, penambahan modal kerja, kondisi ekonomi dan politik negara, serta ketersediaan tenaga kerja.

Tingkat penerapan SMM pada pemindangan higienis UD Cindy Group berada diantara tahap keempat (SQC) dengan nilai 2,31 dan tingkat keenam (TQM) dengan nilai 2,35 (Tabel 2) dari enam tingkat penerapan SMM sesuai Feigenbaum dalam Muhandri dan Kadarisman (2006). Skor yang diperoleh untuk SQC dan TQM apabila dibulatkan adalah dua, yaitu "setuju". SQC artinya telah dilakukan pemeriksaan terhadap contoh, sedangkan TQM artinya 
menitikberatkan pada pendekatan mutu dari berbagai aspek manajemen. Hasil kuesioner menunjukkan pemindangan higienis berada di dua tahapan yang berbeda. Hal ini disebabkan karena UD Cindy Group belum menerapkan TQM secara menyeluruh pada berbagai aspek manajemen. Penerapan TQM pada pemindang-an higienis saat ini baru dilakukan pada aspek produksi, karena UD Cindy Group lebih fokus memuaskan konsumen dari jaminan produknya.

Tabel 2. Tingkat penerapan SMM

\begin{tabular}{llcc}
\hline No & \multicolumn{1}{c}{ Jenis Usaha } & $\begin{array}{c}\text { Tahapan } \\
\text { SMM }\end{array}$ & $\begin{array}{c}\text { Nilai/ } \\
\text { skor }\end{array}$ \\
\hline \multirow{2}{*}{1} & Pemindangan & OQC & 1,9 \\
& Tradisional & FQC & 2.35 \\
2 & Pemindangan Higienis & SQC & 2.31 \\
& & TQM & 2.35 \\
\hline
\end{tabular}

\section{Kinerja Perusahaan}

Kajian kinerja perusahaan dalam penelitian berdasarkan kinerja rataan tiga tahun dilakukan terhadap kinerja Keuangan dan Non Keuangan. Kajian Kinerja Keuangan ditinjau terhadap NPM, ROI, serta ROE dapat dilihat pada Tabel 3. Analisis dilakukan dengan analisis trend rasio. Analisis dengan trend rasio akan dapat menunjukkan suatu pos itu mempunyai kecenderungan atau arah yang menurun, meningkat atau tetap serta menunjukkan apakah kecenderungan atau tendensi yang menguntungkan atau tidak menguntungkan (Munawir, 2004).

Setiap perusahaan menginginkan dan berusaha mengejar laba sebesar-besarnya. Semakin besar laba, semakin baik. Akan tetapi, laba yang besar belum tentu menggambarkan bahwa perusahaan telah dikelola dengan baik. Untuk melihat apakah perusahaan A lebih baik dibandingkan dari perusahaan B maka harus melihat faktor lainnya, misalnya pendapatan atau hasil penjualan.

NPM merupakan rasio laba bersih atas penjualan atau kadang-kadang disebut juga Return on Sales (ROS). Rasio ini dapat dipakai untuk memperkirakan atau meramalkan laba bersih perusahaan pada masa mendatang atas dasar estimasi penjualannya. Naiknya NPM pada tahun 2015 dikarenakan penjualan produk mengalami peningkatan dan penurunan pada tahun 2016 disebabkan penjualan barang produksi menurun. Penurunan merupakan petunjuk bahwa perusahaan perlu dibenahi agar kemampuan menghasilkan laba dapat kembali meningkat. Selain itu juga adanya kebijakan dari pemerintah yang turut menjadi faktor penurunan produksi di tahun 2016 yaitu pembatasan kuota impor ikan pada saat itu. Analisis tren menunjukkan nilai NPM pada pemindangan tradisional dan higienis pada rataan tiga tahun terakhir adalah stabil.

\section{PEMINDANGAN \\ UDCINDY GROUP}

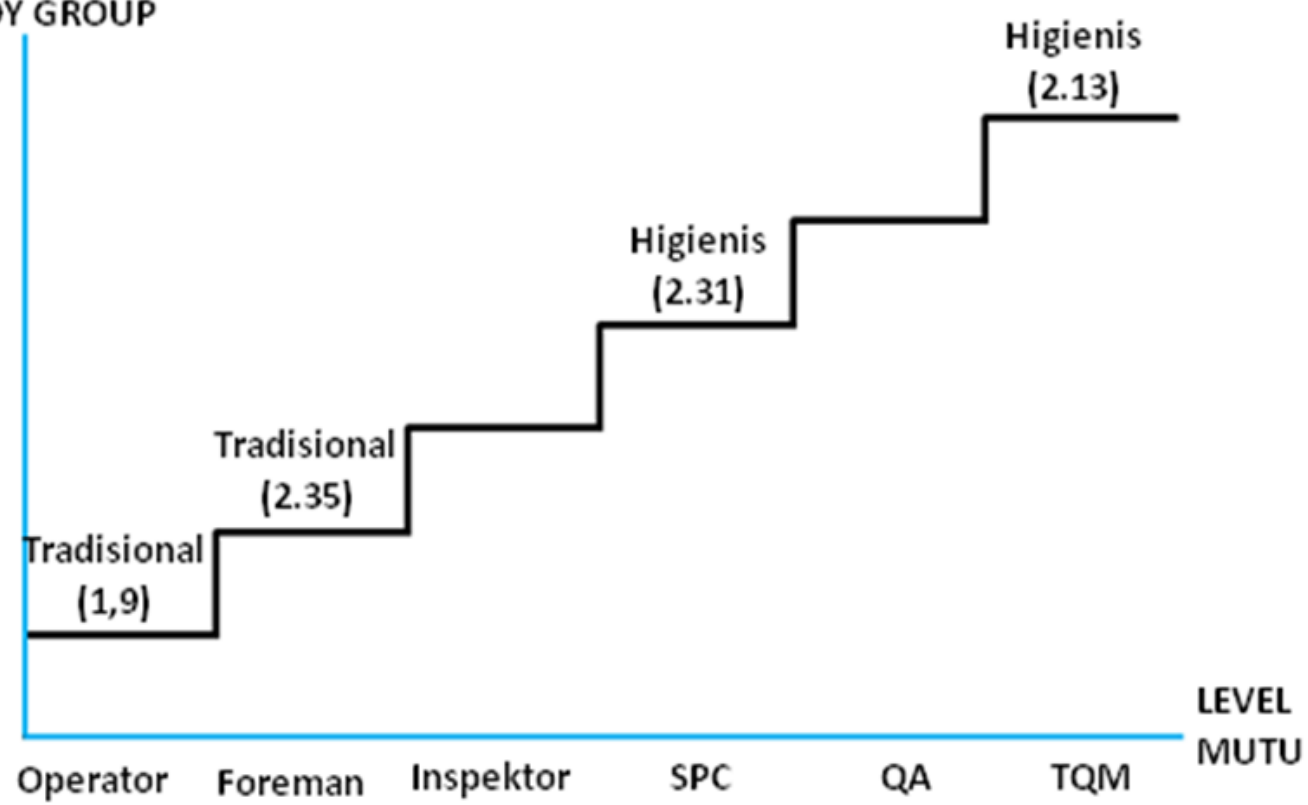

Gambar 1. Tingkat penerapan manajemen mutu UD Cindy Group 
Tabel 3. Hasil analisis tren kinerja perusahaan UD Cindy Group

\begin{tabular}{|c|c|c|c|c|c|c|}
\hline & Kinerja Perusahaan & Jenis Pindang & 2014 & 2015 & 2016 & Tren $(\%)$ \\
\hline \multirow[t]{6}{*}{ Keuangan } & \multirow[t]{2}{*}{ NPM (\%) } & Tradisional & 54 & 54 & 54 & 0 \\
\hline & & Higienis & 17 & 17 & 17 & 0 \\
\hline & \multirow[t]{2}{*}{ ROI (\%) } & Tradisional & 92,93 & 92,93 & 9,74 & $-0,22$ \\
\hline & & Higienis & 13,14 & 13,65 & 12,77 & $-2,84$ \\
\hline & \multirow[t]{2}{*}{ ROE (\%) } & Tradisional & 125,45 & 120,02 & 115,92 & $-1,98$ \\
\hline & & Higienis & 17,74 & 17,75 & 15,96 & $-2,64$ \\
\hline \multirow{6}{*}{$\begin{array}{l}\text { Non } \\
\text { Keuangan }\end{array}$} & \multirow[t]{3}{*}{ Jumlah Pelatihan } & Tradisional & 1 & 1 & 1 & 0 \\
\hline & & Higienis & 3 & 3 & 3 & 0 \\
\hline & & Tradisional & 305 & 337 & 280 & 6 \\
\hline & \multirow[t]{2}{*}{ Volume Produksi (ton) } & Higienis & 87 & 97 & 77 & 7 \\
\hline & & Tradisional & 15 & 12 & 12 & -8 \\
\hline & Jumlah Pelanggan (orang) & Higienis & 35 & 43 & 58 & 27 \\
\hline
\end{tabular}

Nilai ROI dapat menggambarkan kemampuan perusahaan dalam hal ini pindang tradisional dan pindang higienis untuk menghasilkan keuntungan yang akan digunakan untuk menutup investasi yang dikeluarkan. Dalam periode tahun 2014-2016, terjadi fluktuasi nilai ROI usaha pindang tradisional dan higienis. Hal ini disebabkan oleh komposisi nilai aset yang dimiliki. Nilai ROI paling tinggi usaha pindang tradisional diperoleh pada tahun 2014 sebesar $92,93 \%$ dan paling rendah diperoleh pada tahun 2015 sebesar 92,32\%. Sementara itu pada pindang higienis, nilai ROI tertinggi justru diperoleh pada tahun 2015 sebesar 13,65\%. Nilai ROI untuk usaha pindang tradisional maupun higienis memiliki tren negatif/menurun pada rataan tiga tahun terakhir. Penelitian Pertiwi dan Pratama (2012) menyatakan bahwa ROI berpengaruh terhadap nilai perusahaan food and beverage. Yuniasih dan Wirakusuma (2007) menunjukkan bahwa ROA terbukti berpengaruh positif pada nilai perusahaan manufaktur.

ROE sangat berguna bagi para penanam modal atau pemilik perusahaan. Rasio ini membuat manajemen dapat melihat besarnya laba bersih yang dapat dihasilkan dari jumlah total modal yang ditanam. Secara umum bila dibandingkan dari tahun 2014-2016, terjadi fluktuasi dalam jumlah modal yang dikeluarkan pada usaha pindang tradisional dan higienis. Modal paling besar dikeluarkan pada pindang tradisional dan higienis adalah tahun 2015. Bila dibandingkan dengan tahun 2014, maka jumlah modal yang dikeluarkan pada tahun 2016 mengalami penurunan $0,34 \%$ untuk pindang tradisional dan meningkat untuk pindang higienis
0,43\%. Nilai tren ROE pada pemindangan tradisional dan higienis pada tiga rataan terakhir mengalami penurunan. Fluktuasi nilai ROE ini dipengaruhi oleh beberapa faktor, antara lain volume penjualan, harga jual produk dan persentase modal yang diinvestasikan. Penelitian sebelumnya yang dilakukan oleh Anindya dan Agustin (2015); Lumban B, Maulina dan Gumilar (2012) menyimpulkan bahwa ROE berpengaruh terhadap nilai perusahaan.

Jumlah pelatihan pada UD Cindy Group adalah tetap, tidak mengalami peningkatan dan penurunan. Materi dari pelatihan ada yang sama ataupun berbeda dari tahun sebelumnya. Jumlah pelatihan pada pindang higienis lebih besar daripada pindang tradisional. Hal ini karena adanya tuntutan jaminan mutu yang lebih besar pada produk pindang higienis oleh konsumen. UD Cindy Group saat ini belum melakukan peningkatan kompetensi karyawan, terlihat dari tidak adanya peningkatan jumlah pelatihan yang diikuti. Penelitian Lasima et al. (2012) menyimpulkan bahwa dari semua tingkatan penerapan manajemen mutu SQC, QA maupun TQM terdapat empat faktor dominan yang memengaruhi kinerja perusahaan, yaitu efisiensi biaya, persentase S1 (sarjana), persentase SDM yang mengikuti pelatihan per tahun dan persentase keluhan pelanggan. Menurut Kusumawardani et al. (2012), manajemen mutu berkaitan dengan SDM pada suatu perusahaan, maka yang perlu dilakukan perusahaan untuk menerapkan manajemen mutu adalah dengan menempatkan SDM sesuai kompetensinya, identifikasi kompetensi yang dibutuhkan, penyediaan pelatihan, evaluasi efektivitas pelatihan, pemahaman tentang keter- 
kaitan dan pentingnya kegiatan yang dilakukan, serta pemeliharaan catatan pendidikan, pengalaman, pelatihan dan kualifikasi SDM. Pelatihan bagi pekerja perlu diadakan, sehingga keterampilan pekerja dapat meningkat.

Volume produksi pindang tradisional mengalami peningkatan pada tahun 2015, sedangkan tahun 2016 mengalami penurunan. Begitu juga dengan volume produksi pindang higienis mengalami peningkatan pada tahun 2015 dan mengalami penurunan pada tahun 2016. Berdasarkan tren rataan tahunan, pindang tradisional dan higienis mengalami peningkatan dimana nilai tren pindang higienis lebih tinggi dibandingkan pindang tradisional. Nilai tren pindang higienis yang lebih tinggi menunjukkan bahwa permintaan produk pindang higienis meningkat seiring dengan perkembangan pengetahuan konsumen akan produk yang bermutu.

Jumlah pelanggan untuk pemindangan tradisional dari tahun 2014 sampai tahun 2016 mengalami penurunan. Hal ini menunjukkan bahwa beberapa pelanggan mengalami ketidakpuasan atas produk pindang tradisional atau beralih ke produk lainnya. Jumlah pelanggan pemindangan higienis dari tahun 2014-2016 mengalami peningkatan. Tahun 2014 jumlah pelanggan 35 orang dengan 5 orang menjadi agen. Tahun 2015 jumlah pelanggan menjadi 43 orang dengan 8 orang menjadi agen. Tahun 2016 jumlah pelanggan menjadi 58 orang dengan 10 orang menjadi agen. Pelanggan yang menjadi agen produk pindang higienis UD Cindy Group tersebar di wilayah Jabodetabek. Hal ini menunjukkan bahwa pindang higienis memiliki keunggulan dan mampu bersaing di pasaran.

\section{Hubungan Tingkat Penerapan SMM dengan Kinerja Perusahaan}

1. Hubungan tingkat penerapan SMM dengan kinerja keuangan

Hubungan tingkat penerapan SMM dengan kinerja perusahaan UD Cindy Group dapat dilihat bahwa tingkat penerapan SMM pada pemindangan tradisional yang berada di tahap penerapan tingkat OQC dan FQC dengan kinerja keuangan perusahaan terhadap NPM, ROI dan ROE, yaitu mengalami tren stabil untuk NPM dan mengalami penurunan pada tren ROI dan ROE. Penurunan dapat disebabkan seringnya terjadi ketidaksesuaian terhadap produk karena pemeriksaan mutu tidak dilakukan secara menyeluruh, sehingga rasio laba atas modal dan asset menjadi menurun. Ketersediaan stok bahan baku ikan beku yang tidak selalu ada merupakan faktor menurunnya kinerja keuangan pada industri pemindangan.

Hubungan tingkat penerapan SMM dengan kinerja keuangan pada pemindangan higienis yang berada di tahap penerapan tingkat SQC dan TQM, yaitu mengalami tren stabil untuk NPM dan mengalami penurun-an pada tren ROI dan ROE. Hal ini disebabkan masih terbatasnya pemasaran produk pindang higienis. Manajemen pemasaran belum dikelola dengan baik. Kekurangan SDM khususnya pemasaran menjadi hal yang perlu diperhatikan lebih lanjut, agar pemasaran produk pindang higienis mampu bersaing di pasar nasional. Perlunya penambahan tenaga kerja di bagian pemasaran merupakan faktor kunci dalam peningkatan (growth) kinerja keuangan pada industri pemindangan higienis.

Penurunan tren ROI dan ROE pada pemindangan higienis lebih besar daripada pemindangan tradisional. Hal ini disebabkan besarnya modal yang dikeluarkan pada tahun pertama dan kedua sehingga laba yang diperoleh masih sedikit sehingga memengaruhi nilai rasio laba bersih, sedangkan modal yang dikeluarkan pemindangan tradisional lebih kecil dan produksi telah dimulai jauh sebelum pemindangan higienis. Menurut Munawir (2004), rasio yang rendah menunjukkan kemungkinan-kemungkinan berikut: (a) adanya turn over investment dalam aktiva yang digunakan untuk operasional dalam hubungannya dengan volume penjualan; (b) merupakan cermin rendahnya volume penjualan dibandingkan dengan ongkos-ongkos yang diperlukan; (c) adanya inefisiensi, baik dalam produksi, pembelian maupun pemasaran; dan (d) adanya kegiatan ekonomi yang menurun.

2. Hubungan tingkat penerapan manajemen mutu dengan kinerja non keuangan.

Hubungan tingkat penerapan SMM dengan kinerja perusahaan non keuangan bahwa tingkat penerapan SMM untuk industri pemindangan tradisional yang berada pada tahap penerapan antara OQC dan FQC tidak mengalami peningkatan pada tren jumlah pelatihan dan jumlah pelanggan, sedangkan pada tren volume produksi bernilai positif atau meningkat. Sementara pada industri pemindangan higienis, tahap penerapan antara 
SQC dan TQM mengalami peningkatan pada tren jumlah pelanggan dan volume produksi. Mutu produk yang terjaga merupakan faktor penting dalam meningkatkan kinerja industri pemindangan higienis, terutama peningkatan volume produksi dan jumlah pelanggan. Berdasarkan hal ini kita melihat betapa pentingnya penerapan SMM pada industri pemindangan higienis dalam meningkatkan kinerja perusahaan, karena dapat meningkatkan jumlah pelanggan. Jumlah pelanggan merupakan faktor penting pada peningkatan penjualan produk, karena semakin banyak jumlah pelanggan, maka semakin banyak juga penjualan produknya. Peningkatan kinerja non keuangan pada pemindangan higienis yang berada pada tahap SQC sesuai dengan penelitian Panjaitan (2011) yang menyimpulkan bahwa tingkat penerapan manajemen mutu pada tahap SQC mengalami peningkatan terhadap kinerja keuangan maupun non keuangan.

3. Pengaruh Kinerja Keuangan dan Non Keuangan terhadap Kinerja Perusahaan

Hasil analisis diskriminan menunjukkan bahwa kinerja rataan perusahaan baik keuangan maupun non keuangan antara usaha pindang tradisional dan higienis berbeda secara nyata. Hal ini dapat dilihat dari nilai hasil uji Wilks Lambda dengan nilai nyata $<0,05$ seperti disajikan pada Tabel 4. Kinerja keuangan dan non keuangan yang berbeda nyata ini mengindikasikan bahwa tahapan penerapan SMM memberikan pengaruh yang nyata terhadap pencapaian masing-masing unit usaha. Semakin tinggi penerapan SMM, maka kinerja perusahaan akan semakin baik.

Peubah NPM dan jumlah pelatihan yang diikuti oleh masing-masing karyawan pada usaha pindang tradisional dan higienis tidak dapat dihitung pada analisis diskriminan dikarenakan angkanya tetap atau stabil pada tiga tahun terakhir (2014-2016). Hal ini mengindikasikan bahwa perusahaan belum melakukan upaya berbeda untuk meningkatkan keterampilan tenaga kerjanya melalui proses pelatihan serta belum ada perubahan rasio laba bersih terhadap keuntungan baik pada pindang tradisional maupun higienis.

Peubah NPM dan jumlah pelatihan tidak dapat dianalisis karena memiliki nilai yang stabil pada rataan tiga tahun terakhir (dilambangkan dengan "a"). Peubah ROI, ROE, volume produksi dan jumlah pelanggan berbeda nyata antara usaha pindang tradisional dan higienis selanjutnya dipilih sebagai peubah yang berdampak nyata pada perusahaan. Namun demikian berdasarkan uji validitas model diskriminan diperoleh bahwa peubah yang benar-benar berbeda nyata adalah peubah ROI.

Nlilai ROI yang berbeda nyata menunjukkan usaha pindang tradisional dan higienis tersebut mampu memberikan pengembalian investasi dengan laba yang dihasilkan perusahaan. Nilai ROI yang semakin tinggi juga menunjukkan semakin cepat pengembalian investasi yang dilakukan. Nilai ROI pada pindang tradisional lebih besar daripada pindang higienis. Untuk meningkatkan kinerja perusahaan, maka UD Cindy Group harus meningkatkan mutu SDM, terutama pada bagian produksi, QC dan pemasarannya. Peningkatan volume produksi juga berpengaruh dalam peningkatan nilai ROI untuk meningkatkan pendapatan dan kesejahteraan semua tenaga kerja yang terlibat. Penelitian Ardimas dan Wardoyo (2014) menyimpulkan bahwa peubah kinerja keuangan yang diukur dengan ROI dan ROE mempunyai pengaruh

Tabel 4. Hasil analisis diskriminan

\begin{tabular}{|c|c|c|}
\hline Peubah & Wilks' Lambda & Sig. \\
\hline NPM &. $\mathrm{a}$ & \\
\hline ROI & 0,000 & 0,000 \\
\hline ROE & 0,003 & 0,000 \\
\hline Volume produksi & 0,250 & 0,000 \\
\hline Jumlah pelanggan & 0,151 & 0,009 \\
\hline Jumlah pelatihan & .a & \\
\hline \multicolumn{3}{|c|}{ Variables in the Analysis } \\
\hline 1 & ROI & 0,000 \\
\hline
\end{tabular}


nyata, sedangkan NPM tidak mempunyai pengaruh nyata terhadap nilai perusahaan pada perusahaan sektor perbankan yang go public di Bursa Efek Indonesia.

\section{KESIMPULAN}

Tingkat penerapan manajemen mutu UD Cindy Group pada pemindangan tradisional masih rendah (berada diantara OQC dan FQC) dan pemindangan higienis sudah berada pada tahap diantara SQC dan TQM. Penerapan TQM pada pemindangan higienis masih belum menyeluruh pada semua aspek manajemen, TQM baru dilakukan pada aspek produksi. Pemindangan higienis saat ini lebih fokus pada tahap pemuasan konsumen.

Hasil kajian analisis diskriminan menunjukkan bahwa tingkat penerapan SMM berpengaruh terhadap kinerja perusahaan UD Cindy Group, yaitu pada kinerja keuangan dan non keuangan. Pada pemindangan higienis memiliki tren volume produksi dan jumlah pelanggan yang meningkat pada rataan tiga tahun terakhir.

Peningkatkan volume produksi pada pemindangan higienis harus bersama-sama dengan peningkatan SDM dan manajemen perusahaan agar diperoleh pendapatan optimal. Pada pemindangan tradisional diperoleh nilai ROI dan ROE yang tinggi menunjukkan bahwa pemindangan tradisional lebih cepat melakukan aktivitas pengembalian modal, tetapi dari segi kinerja non keuangan terlihat tren yang menurun sehingga diperlukan peningkatan penerapan SMM agar mampu berdaya saing.

\section{DAFTAR PUSTAKA}

Anindya, I.W., S. Agustin. 2015. Analisis Pengaruh Kinerja Keuangan terhadap Harga Saham pada Perusahaan Perkebunan Indonesia. Jurnal Ilmu dan Riset Manajemen, 4(1).

Ardimas, W., Wardoyo. 2014. Pengaruh Kinerja Keuangan dan Corporate Social Responsibility terhadap Nilai Perusahaan pada Bank Go Public yang terdaftar di BEI. Jurnal Manajemen dan Bisnis, 18(1): 57-66.
Heruwati, E.S. 2002. Pengolahan Ikan secara Tradisional: Prospek dan Peluang Pengembangan. Jurnal Litbang Pertanian, 21(3): 92 99.

[KKP] Kementerian Kelautan dan Perikanan. dalam Angka. 2012. Jumlah Unit Pengolahan Ikan Tradisional di Indonesia Tahun 2009-2012 (Diolah). Jakarta (ID): KKP.

Kusumawardani, D.S., M. Sarma, A. Munandar. 2012. Tingkat Penerapan Manajemen Mutu pada Usaha IKM Chide Wrought Iron Design. Manajemen IKM, 7(2): 152-165.

Lasima, W., M. Syamsun, D. Kadarisman. 2012. Tingkat Penerapan Manajemen Mutu pada UMKM Pembenihan Udang di Jawa Timur. Manajemen IKM, 7(2): 143-151.

Lumban, R.M., I. Maulina, I. Gumilar. 2012. Analisis Pengembangan Usaha Pemindangan Ikan di Kecamatan Bekasi Barat. Jurnal Per-ikanan dan Kelautan, 3(1): 17-24.

Muhandri, T., D. Kadarisman. 2006. Sistem Jaminan Mutu Industri Pangan. Bogor (ID): IPB Press.

Munawir, S. 2004. Analisa Laporan Keuangan. Yogyakarta (ID): Liberty Yogyakarta.

Panjaitan, L.E. 2011. Kajian Tingkat Penerapan Manajemen Mutu terhadap Kinerja UMKM Sektor Agro-Industri Pangan Olahan Nata de Coco di Kota Bogor [tesis]. Bogor (ID): Institut Pertanian Bogor.

Pertiwi, P. 2012. Pengaruh Kinerja Keuangan, Good Corporate Governance terhadap Nilai Perusahaan Food and Beverages. Jurnal Manajemen dan Kewira-usahaan, 14(2): 118-127.

Wardana, R. 2006. Penerapan Sistem Manajemen Mutu dalam Meningkatkan Kinerja Usaha IKM (Kasus di PT. Sapukurat Kharisma) [tesis]. Bogor (ID): Institut Pertanian Bogor.

Yuniasih, N.W., M.G. Wirakusuma. 2009. Pengaruh Kinerja Keuangan terhadap Nilai Perusahaan dengan Pengungkapan Corporate Social Responsibility dan Good Corporate Governance sebagai Variabel Pemoderasi. Jurnal Akuntansi, 4(1): 109127. 